\title{
Determination of administrative proficiencies of head nurses in Turkısh Hospitals ${ }^{1}$
}

\author{
Sultan Türkmen ${ }^{2}$ \\ Filiz Hisar ${ }^{3}$
}

\begin{abstract}
Background: The head nurses are the ones who are responsible for operating care units and managing the nurses in the unit. They are required to have the administrative skills needed to perform these duties

Aim: This study was carried out with the aim of determining the administrative proficiency of head nurses.

Methods: The study population comprised head nurses, including nursing instructors working in public and university hospitals in Turkey. The sample included 511 head nurses who were selected within the seven geographical regions of Turkey by simple random sampling. The data gathered in the study, demographic information forms, and the Head Nurse Proficiency Rating Scale were assessed with the t-test in number, percent, and independent groups, one-way analysis of variance, and Tukey Tests.

Results: In this study the proficiency level of the head nurses working in Turkey was examined. It was found that they were most proficient in the management of general units and least proficient in care management; but insufficient in planning the future assignment/ career of their employees of subgroups of scala. When considering the factors associated with competencies of the service head nurse; significant statistical differences between all personal characteristics (except professional experience, former training for executive competency and the willing for execution training and competency) and competency were established $(p<0.05)$.

Conclusion: In the light of these results it is suggested that programmes should be provided by schools of nursing, hospitals, the Ministry of Health and occupational nursing organizations for developing proficiency behaviours consisting of care management and personnel management.
\end{abstract}

Keywords: Head Nurse; Health Care; Administrative Proficiencies; Nursing; Proficiency.

\section{Introduction}

In parallel with the changes and developments taking place in many sectors nowadays, the prominence of a proficient workforce and specialisation in service delivery has made essential the determination and development of managers' proficiency. Such proficiency includes the skills, knowledge, and abilities needed to perform a task efficiently and carry out the responsibilities required by the task (Brazil et al 2013; Akemine et al., 2013).

Managers with sufficient knowledge and abilities are required for the delivery of efficient and proficient services in medical institutions. The majority of human resources in hospitals are comprised of nurses. Delivery of effective and efficient service is therefore the responsibility of

\footnotetext{
1 This research is a part of MSc thesis of Sultan Türkmen.

2 RN, Master degree, Ankara University Faculty of Health Science, Department of Nursing, sultan t@hotmail.com

${ }^{3}$ RN, Ph.D. Associate Professor, Necmettin Erbakan University, Faculty of Health Science, Department of Nursing, filiz.hisar@gmail.com
} 
Türkmen, S., \& Hisar, F. (2016). Determination of administrative proficiencies of head nurses in Turkish Hospitals. Journal of Human Sciences, 13(2), 3204-3210. doi:10.14687/jhs.v13i2.3706

the nursing services (Kavuncubaşı, 2010; McCarthy \& Fitzpatrick, 2009; Geçkil et al 2008). The head nurses involved in the first step of the administration play an important role in managing the nursing services efficiently. No matter how pertinent the decisions made at the top level, their success depends on the low-level managers who implement and monitor them. The success of the head nurses in unit management, and the quality and efficiency of the services provided are directly proportionate to the proficiencies these individuals have as nurses, managers, and leaders (Lorber \& Savič 2011; Johansson et al., 2007).

In Turkey, various studies have determined that managers are not properly trained or the jobs they do, the power and responsibilities of jobs are not standardised, staff are not given any preliminary or in-service training programmes when they are assigned or reassigned, and performance assessment and success criteria are not definitive (Lorber \& Savič, 2011; Kavuncubaşı \& Yıldırım 2010). These results suggest that head nurses' skills need to be enhanced so that knowledge, attitude and behaviour objectives are met in order to develop better nursing services. Although there are various studies regarding the determination of the proficiencies of head nurses worldwide, there are only one studies that focus on Turkey as far as we can ascertain (Lorber \& Savič 2011; Duffield \& Franks, 2001; Pillay, 2008; Sökmen, 2005.) Therefore, we planned to address this gap in the literature.

\section{Purpose}

To determine the administrative proficiencies of the head nurses on duty in public and university hospitals in Turkey.

\section{Methods}

\section{Setting and Sample}

The population of the study consisted of all head nurses working in public and university hospitals in Turkey. Seven geographical regions were used for sampling. For stratified sampling, Turkey was divided into seven geographical regions, and one province was chosen from each region. One university and one public hospital with inpatient bed availability were chosen from each region. The reason for including the hospitals with the highest bed availability in the sampling was the consideration that administrative arrangements run parallel to workload. The total number of head nurses in fourteen hospitals was 609 and 511 participants completed the research forms, giving a response rate of $84 \%$. The assessment of 511 head nurses was therefore carried out.

\section{Data Collection}

Prior to data collection, written consent was obtained from all the institutions studied. Data were collected between February and July 2011. The Head Nurse Proficiency Rating Scale (HNPRS) was used for data collection. Data collection forms were filled out by the nurses themselves. Respondents' willingness to complete the inventory was seen as an indication of consent. The data were collected during a week spent at each institution.

\section{Instrument}

The current study was used to collect data through the HNPRS which was developed by Sökmen (2005). This scale includes 45 items, and three subgroups: General Unit Management, Staff Management, and Care Management. Answers were given on a five-point Likert-type scale $(1=\mathrm{I}$ am not proficient at all; $2=\mathrm{I}$ am a little proficient; $3=\mathrm{I}$ am not certain; $4=\mathrm{I}$ am mostly proficient; and $5=\mathrm{I}$ am completely proficient). Cronbach's alpha for the internal consistency of the entire HNPRS was 0.95. Scale was evaluated with the original evaluation criteria. The assessment assumed the scale was equal interval and gave a value of 0.80 to each interval (since the scale has five grades with four intervals, each interval is considered as $4 / 5=0.80 ; 1.00-1.80$; 
Türkmen, S., \& Hisar, F. (2016). Determination of administrative proficiencies of head nurses in Turkish Hospitals. Journal of Human Sciences, 13(2), 3204-3210. doi:10.14687/jhs.v13i2.3706

$1.81-2.60 ; 2.61-3.40 ; 3.41-4.20 ; 4.21-5.00)$. If the points obtained from the total scale subgroups were under the mean limit value (3.40), it was assumed there were inefficiencies (Sökmen, 2005).

\section{Data Analysis}

The data were evaluated with the SPSS 15.0 program (SPSS Inc., Chicago, IL, USA). The inventory was evaluated with the original evaluation criteria. In the statistical analysis of the data, the frequency, percent, mean, standard deviation, one-way analysis of variance. Tukey Test, and ttest in independent groups were used.

Ethical Approval The ethical consent that is required for the performance of the research was obtained from Hacettepe University Ethics Committee (Number: 240-3218; Date: 26.11.2010)

\section{Results}

Table 1: Demographics (Number $=511)$

\begin{tabular}{lcc}
\hline Characteristic & N & $\%$ \\
\hline Education & 41 & 8.0 \\
Vocational School of Health & 244 & 47.7 \\
Associate Degree & 191 & 37.4 \\
Undergraduate & 35 & 6.9 \\
Postgraduate & 266 & 52.1 \\
\hline Institution Worked In & 245 & 47.9 \\
University Hospital & 244 & \\
Hospital of Ministry of Health & 135 & 47.7 \\
\hline Duration of Management Experience & 74 & 26.4 \\
$1-5$ & 58 & 14.5 \\
$6-10$ & 179 & 11.4 \\
$11-15$ & 332 & 35.0 \\
$16+$ & & 65.0 \\
\hline Have you participated in a management training programme? & \\
Yes & 179 & \\
\hline
\end{tabular}

A total of 511 head nurses participated in the study. As seen in Table 1, 47.7\% had an associate degree in nursing, $47.7 \%$ had administrative experience of one to five years, and more than half $(65 \%)$ had no training in nursing management.

Table 2: Distribution of the Mean Scores Service Head Nurses Obtained on the SHNPRS Subscales ( $(n=511)$ 
Türkmen, S., \& Hisar, F. (2016). Determination of administrative proficiencies of head nurses in Turkish Hospitals. Journal of Human Sciences, 13(2), 3204-3210. doi:10.14687/jhs.v13i2.3706

\begin{tabular}{|l|c|c|c|c|}
\hline Scale Sub-Dimensions & Minimum & Maximum & $\overline{\mathrm{X}}$ & $\mathrm{SD}$ \\
General Unit Management & 1.00 & 5.00 & 4.22 & 0.50 \\
Personnel Management & 1.00 & 5.00 & 4.16 & 0.54 \\
Care Management & 1.00 & 5.00 & 4.07 & 0.63 \\
Scale General Point Mean & 1.00 & 5.00 & 4.17 & 0.51 \\
\hline
\end{tabular}

Table 2 shows the distribution of the mean scores of head nurses obtained from the HNPRS subscales. The mean score of nurses was $\mathrm{X}=4.17 \pm 0.51$ : the area with low mean scores was staff management $(x=4.07 \pm 0.63$, and the area with the highest score was general unit management $(\mathrm{X}=4.22 \pm 0.50)$.

Table 3: SHNPRS Mean Scores of Service Head Nurses According to Socio-Demographic Characteristics $(n=511)$

Proficiency

Definitive Features

$\overline{\mathrm{X}}+\mathrm{SD} \quad$ Lower Limit Upper Limit $\quad$ Test $\quad$ P

\begin{tabular}{|c|c|c|c|c|c|c|}
\hline \multirow{4}{*}{ Education } & Vocational School of Health & $4.00 \pm 0.58$ & 3.81 & 4.18 & \multirow{4}{*}{$F=4.995$} & \multirow{4}{*}{$0.002^{*}$} \\
\hline & Associate Degree & $4.17 \pm 0.51$ & 4.10 & 4.23 & & \\
\hline & Undergraduate & $4.15 \pm 0.48$ & 4.08 & 4.22 & & \\
\hline & Postgraduate & $4.43 \pm 0.35$ & 4.31 & 4.56 & & \\
\hline \multirow{2}{*}{$\begin{array}{l}\text { Institution } \\
\text { Worked In }\end{array}$} & $\begin{array}{l}\text { Hospital of Ministry of } \\
\text { Health }\end{array}$ & $4.12 \pm 0.55$ & 4.05 & 4.19 & \multirow[t]{2}{*}{$\mathrm{t}=-1.80$} & \multirow[t]{2}{*}{$0.022^{*}$} \\
\hline & University Hospital & $4.20 \pm 0.45$ & 4.15 & 4.26 & & \\
\hline \multirow{4}{*}{$\begin{array}{l}\text { Management } \\
\text { Experience }\end{array}$} & $1-5$ years & $4.09 \pm 0.53$ & 4.02 & 4.15 & \multirow{4}{*}{$\mathrm{F}=5.35$} & \multirow{4}{*}{$0.001^{*}$} \\
\hline & $6-10$ years & $4.18 \pm 0.45$ & 4.10 & 4.26 & & \\
\hline & $11-15$ years & $4.30 \pm 0.48$ & 4.19 & 4.41 & & \\
\hline & $16+$ & $4.29 \pm 0.46$ & 4.18 & 4.42 & & \\
\hline
\end{tabular}

${ }^{*} \mathrm{p}<0.05$

As seen in Table 3, the lowest HNPRS score was for nurses who had trained at a vocational school of health $(\mathrm{X}=4.00 \pm 0.58)$, whereas the nurses who had postgraduate degrees in nursing had the highest scores $(x=4.43 \pm 0.35$ ). The difference between the groups was found to be statistically significant $(p<0.05)$. The mean HNPRS score was highest in the group who had been working as nurse managers for 11 to 15 years $(X=4.30 \pm 0.48)$ and lowest in the group who had worked as nurse managers for six to ten years $(x=4.18 \pm 0.45)$. The difference between the groups was found to be statistically significant $(p<0.05)$.

\section{Discussion}


Türkmen, S., \& Hisar, F. (2016). Determination of administrative proficiencies of head nurses in Turkish Hospitals. Journal of Human Sciences, 13(2), 3204-3210. doi:10.14687/ihs.v13i2.3706

The head nurses are the ones who are responsible for operating care units and managing the nurses in the unit. They are required to have the administrative skills needed to perform these duties. So this study was conducted to determine the administrative proficiency levels of head nurses. In the present study, the administrative proficiencies and conduct of head nurses were found to be quite low compared to findings in other studies (Pillay, 2009). I several aspects of proficiencies led to this situation.

\section{General Unit Management}

General unit management includes matters such as provision of the necessary physical media for the unit, determination of work flow and objectives, solution of urgent problems to enable everyday work to proceed, preparation of the unit for permanent use of medicine and medical equipment, and the security of employees (Sökmen, 2005).

It was found that the head nurses who participated in our study were proficient in technical fields such as being able to assess the general cleanliness and order of the unit, to be prepared for the permanent use of emergency medicine and medical equipment, and to handle the equipment and materials used periodically in the unit in the sub-dimension of general unit management while They were unproficient in such fields as being able achieve the unit's objectives ability to change to improve the nursing services (Table 2). The results of Sökmen's study (2005) support our results. Duffield, \& Franks (2001) results determined that the activities of keeping order, general cleaning of unit, and control in terms of patient care are the most frequent activities carried out by the nurses. Duties consisting of mostly technical skills are adopted and practised by the head nurses, which accounts for this situation.

\section{Staff Management}

The responsibility of head nurses in staff management is to direct the right people in sufficient numbers to the right jobs in the right place at the right time (Pillay, 2011; Brazil, et al 2013). Duffield, \& Franks (2001). determined that managers need to encourage the occupational development of nursing staff and improve their performance.

We found that the head nurses were proficient in fields such as preparing the work schedules and scheduling leave (annual, etc.) of employees and non-proficient in the field of planning future duties/careers. Sökmen (2005) found that head nurses were proficient in arranging work schedules. Aydoğan (2007) found that the activity of deciding on the number of nurses and personnel needed for the service was among the first ten management activities for which head nurses were responsible.

It was found that the head nurses were least proficient in fields such as utilising the research in nursing services/care, use of scientific methods in nursing care, and applying the nursing care presentation model to operation of the unit in our study (Table 2) Sökmen (2005) found that the head nurses were non-proficient in the fields of motivating employees and planning the future duties/careers of employees.

\section{Care Management}

The finding that care management scored least in the sub-dimensions of the scale was surprising, given that nursing is essentially about care (Table 2). Sökmen (2005) and Pillay (2009) reached similar conclusions, however. What distinguishes nursing from other occupations is the care function. The most important quality indicator of nursing services is the caring. When the care function is not effectively fulfilled it exposes the patient to significant risks.

When head nurses are assigned to managerial positions straight from clinical nursing without any preliminary preparation or training there is confusion regarding their duties and responsibilities. This results in their engagement in administrative duties ends up isolating them from patients and employees. This results in their engaging in administrative duties by isolating themselves from patients and employees. The fact that head nurses do not always provide care directly to patients 
Türkmen, S., \& Hisar, F. (2016). Determination of administrative proficiencies of head nurses in Turkish Hospitals. Journal of Human Sciences, 13(2), 3204-3210. doi:10.14687/jhs.v13i2.3706

does not mean that the fundamental duties of assessment of patient care quality, sustainable provision, and determination of problems and requirements should be disregarded (Kavuncubaş1 \&Yıldırım, 2010; Arman et al. 2009; Skytt et al., 2007; Eren \& Hisar 2016).

Paliadelis (2005) found that head nurses are assigned to their duties without any preliminary training, lacking both knowledge and preparation, factors which engender anger and unwillingness. A lack of standard training which identifies duties and responsibilities clearly and definitively means that head nurses will experience confusion with respect to their new roles and take their former head nurses as role models or learn by trial and error.

When the total mean score of the Head Nurse Proficiency Rating Scale is compared with educational status (Table 3), the lowest point mean for the vocational group shows similarity to Sökmen's study (2005). This suggests that the content and duration of management lessons in vocational schools of health are not sufficient, and their graduates are not supported by management training programmes in the organisations in which they work.

One of the findings of this research was that the majority of head nurses did not participate in any management training programme (Table 1). Given that continuous developments occur in the health area, head nurses should be offered in-house training before and after assignment, and should be supported with continuous training so that they can keep up to date with developments. Although knowledge and skills are developed via training, many studies found that the majority of head nurses did not participate in management training programmes (Lorber \& Savič, 2011; Sökmen, 2005; Ardahan \& Ay, 2006).

When the total point mean of the Head Nurse Proficiency Rating scale was contrasted with nurses' management experience, we saw that the highest scores were obtained by those who had management experience of 16 years and over. Pillay (2011) determined a positive correlation between management experience and head nurses' being more sensitive to their employees' requirements and more open to receiving help from senior management, and thus better meeting the expectations of nurses and organisations.

\section{Conclusions}

In this study the proficiency level of the service head nurses working in Turkey was examined. It was found that they were most proficient in the management of general units and least proficient in care management. The mean was highest in the postgraduate group and lowest in the group with associate degrees $(p<0.05)$. In light of these results, it is suggested that programmes should be provided by schools of nursing, hospitals, the Ministry of Health, and occupational nursing organisations for developing proficiency behaviours consisting of care management and personnel management.

\section{Limitations}

Information on the proficiency levels of head nurses relied solely on their self-assessments, and the assessments of their superiors and peers were not considered.

\section{Author Contributions}

All authors have been accredited as appropriate upon submission of the manuscript according to the International Committee of Medical Journal Editors' authorship criteria. Specifically, all the authors have been involved in the development of the study concept and design, critical revisions for important intellectual content in writing the manuscript, and administrative support. The data collection was performed by the first author.

\section{Conflict of Interest}

There were no conflicts of interest to report. 
Türkmen, S., \& Hisar, F. (2016). Determination of administrative proficiencies of head nurses in Turkish Hospitals. Journal of Human Sciences, 13(2), 3204-3210. doi:10.14687/ihs.v13i2.3706

\section{Source of Funding}

There was no source of funding.

\section{References}

Akemine, I., Oza, M., Shinjo, M., \& Nakamori, E. (2013). Development of competence scale for senior clinical nurses. Japan Journal of Nursing Science, 10(1):55-67.

Ardahan, M., \& Ay, S. (2006). Yönetici hemşirelerde stres belirtileri ve strese yatkınlık üzerine bir araştırma. (A research on stress symptoms and stress factor among executive nurses). Sağllk ve Toplum 16(1):83-90.

Arman, R., Dellve, L., Wikström, E., \& Törnström, L. (2009). What health care managers do: Applying Mintzberg's structured observation method. Journal of Nursing Management 17(6):718-729.

Aydoğan, E. (2007). Servis sorumlu hemşirelerinin servis yönetimine ilişkin görüşleri. (Head nurses' opinions on service management). Unpublished Masters Thesis. Ankara: Hacettepe Üniversitesi Sağllk Bilimleri Enstitüsü.

Brazil, B., Wakefield, DB., Cloutier, MM., Tennen, \& H., Hall, CB. (2010). Organizational culture predicts job satisfaction and perceived clinical effectiveness in pediatric primary care practices. Health Care Management Review, 35(4), 365-371

Duffield, C., \& Franks H. (2001). The role and preparation of first-line nurse managers in Australia: Where are we going and how do we get there? Journal of Nursing Management $9(2): 87-91$.

Eren, H., \& Hisar F. (2016). Quality of work life perceived by nurses and their organizational commitment level, International Journal of Human Sciences, 13(1)1123-1132

Geçkil, E., Dündar, Ö., \& Şahin, T. (2008). Evaluation of patients' satisfaction levels from nursing care at the centre of the city Adıyaman. Sağlık Bilimleri Fakültesi Hemşirelik Dergisi, 41151.

Johansson, G., Pörn, I., Theorell, T., \& Gustafsson B. (2007). A first-line nurse manager's goalprofile. Journal of Clinical Nursing 16(1):149-159.

Kavuncubaşı, Ş, \& Yıldırım, S. (2010). Hastane ve Sağhlk Kurumlar Yönetimi. (Hospital and Health Services Management). 2nd edn. Ankara: Siyasal Kitabevi. pp 40-49

Lorber, M., \& Savič, BS. (2011). Perceptions of managerial competencies, style, and characteristics among professionals in nursing. Croatian Medical Journal 52(2):198-204.

McCarthy, G., \& Fitzpatrick, J. (2009). Development of a competency framework for nurse managers in Ireland. Journal of Continuing Education in Nursing 40(8):1-5.

Paliadelis, PS. (2005). Rural nursing unit managers: Education and support for the role. Rural Remote Health 5(1):325-329.

Pillay, R. (2009). Perceived competencies of nurse managers: A comparative analysis of the public and private sectors in South Africa. African Journal of Business Management 3(9):495-503.

Pillay, R. (2011). The skills gap in nursing management in the south african public health sector Public Health Nursing Public Health Nursing 28 (2):176-185

Pillay, R. (2008). Managerial competencies of hospital managers in South Africa: A survey of managers in the public and private sectors. Human Resources for Health 6(4):1-7.

Skytt, B., Ljunggren, B., \& Carlsson, M. (2007). Reason to leave: The motives of first-line nurse managers for leaving their posts. Journal of Nursing Management 15(3):294-302.

Sökmen, S. (2005). İstanbul'daki kamu hastanelerinde görevli alt kademe yönetici hemşirelerin eğitim įhtiyacının analizi ve yönetici eğitim programı önerisi. (Analysis of managerial educational requirements of head service nurses in public hospitals of İstanbul). Unpublished PhD Thesis. İstanbul Üniversitesi Sağl1k Bilimleri Enstitüsü. İstanbul 